\title{
Perbandingan Efektivitas Penyuluhan Demam Berdarah Dengue dengan Metode Role Play dan Metode Permainan Simulasi terhadap Perilaku Ibu tentang DBD di Kecamatan Medan Deli
}

\author{
Novita Hasiani Simanjuntak \\ Departemen IImu Kesehatan Masyarakat Fakultas Kedokteran Universitas HKBP Nommensen \\ Korespondensi: Novita Hasiani Simanjuntak, Email: novitasimanjuntak@uhn.ac.id
}

\begin{abstract}
Background: Dengue Hemorrhagic Fever (DHF) in Indonesia is a "re-emerging infectious disease". DHF can be prevented by vector control. Human behavior is very influential on dengue vector control, namely the cleanliness of the house and activities. In 2017, DHF cases in Indonesia were 59,047 cases. In North Sumatra Province, there were 5,327 cases, in Medan City as many as 1216 cases, with Medan Deli District as the sub-district with the most cases, with 100 cases.
\end{abstract}

Objective: This study aims to see the improvement of mother's behavior by using the roleplay method and simulation games.

Methods: The research is a quasi-experimental non-equivalent group design. The target population is mothers who live in Medan Deli District. The selection of research subjects by purposive sampling, with the number of subjects in each group is 15 people. This study uses the method of role play and games as a comparison method, with a questionnaire as a measuring tool. Paired t-test to see the increase in the mean of each group, and unpaired $\mathrm{t}$-test to see the difference in the mean value.

Results: The results of the paired t-test data analysis found that these two methods showed significant results, with $p$ values of 0.000 and 0.001 with a mean increase in the role play method of 1.40 and the game method of 1.53. The unpaired t-test was found to have a significant difference between the average post-test scores between the role play method and the game method, the mean post-test score for the role-play method was found to be lower than the post-test score for the game method.

Conclusion: Counseling using the role play method and games provides significant results in increasing maternal behavior about DHF. The game method shows a greater average increase than the role play method.

Keywords: DHF, behavior, counseling methods, role play, games.

\begin{abstract}
Abstrak
Latar belakang: Demam Berdarah Dengue (DBD) di Indonesia adalah "re-emerging infectious disease". DBD dapat dicegah dengan pengendalian vektornya. Perilaku manusia sangat berpengaruh pada pengendalian vektor Dengue, yaitu pada kebersihan rumah, dan aktifitas. Tahun 2017, kasus DBD di Indonesia sebanyak 59.047 kasus. Di Propinsi Sumatera Utara, terdapat 5.327 kasus, di Kota Medan sebanyak 1216 kasus, dengan Kecamatan Medan Deli sebagai kecamatan dengan kasus terbanyak, sebanyak 100 kasus.
\end{abstract}

Tujuan: Penelitian ini bertujuan melihat peningkatan prilaku Ibu dengan memakai metode roleplay dan permainan simulasi. 
Metode: Penelitian berupa quasy experimental non-equivalent group design. Populasi target adalah ibu yang berdomisili di Kecamatan Medan Deli. Pemilihan subjek penelitian dengan purposive sampling, dengan jumlah subjek tiap kelompok adalah 15 orang. Penelitian ini menggunakan metode role play dan permainan sebagai metode yang diperbandingkan, dengan kuesioner sebagai alat ukur. Uji t berpasangan untuk melihat peningkatan rerata tiap kelompok, dan uji t tidak berpasangan untuk melihat perbedaan nilai rerata.

Hasil: Hasil analisis data uji t berpasangan didapati kedua metode ini menunjukkan hasil yang bermakna, dengan nilai $p$ 0,000 dan 0,001 dengan peningkatan rerata pada metode role play sebesar 1.40 dan pada metode permainan sebesar 1.53. Uji t tidak berpasangan didapati terdapat perbedaan yang bermakna antara rerata nilai post tes antara metode role play dengan metode permainan, nilai rerata post tes metode role play didapati lebih rendah dari rerata nilai post tes metode permainan.

Kesimpulan: Penyuluhan dengan metode role play dan permainan memberikan hasil bermakna dalam peningkatan perilaku ibu tentang DBD. Metode permainan menunjukkan peningktan rerata yang lebih besar daripada metode role play.

Kata Kunci: DBD, perilaku, metode penyuluhan, role play, permainan.

\section{Pendahuluan}

Demam Berdarah Dengue (DBD) di Indonesia dikategorikan sebagai "re-emerging infectious disease", hal ini karena insidensi penyakit DBD meningkat secara dramatis di seluruh dunia, dengan lebih dari 2,5 milyar orang atau $40 \%$ dari populasi dunia beresiko terkena penyakit ini. World Health Organization (WHO) mengestimasi sekitar 50 sampai 100 juta orang terinfeksi dengue.1,2

Menurut WHO, Indonesia masuk dalam negara kategori A (berdasarkan variabel endemisitas, yaitu masuk dalam masalah kesehatan masyarakat yang besar, tingginya tingkat rawat inap dan kematian pada usia anak, tingkat hiperendemitas yang tinggi keempat serotipe dan tersebar daerah kota) di wilayah Asia Tenggara, selain dari Bangladesh, India, Maladewa, Myanmar, Sri Langka, Thailand dan Timor-Leste. ${ }^{2}$

Berdasarkan Profil Kesehatan Indonesia tahun 2017, di Indonesia pada tahun 2017 jumlah penderita DBD yang dilaporkan sebanyak 59.047 kasus dengan jumlah kematian sebanyak 444 orang (Incidence Rate/Angka kesakitan= 22,55 per 100.000 penduduk dan Case Fatality Ratelangka kematian= $0,75 \%$ ). ${ }^{3}$

Di Propinsi Sumatera Utara, berdasarkan Profil Kesehatan Indonesia tahun 2017, jumlah penderita DBD yang dilaporkan sebanyak 5.327 kasus dengan jumlah kematian sebanyak 29 orang (Incidence Rate/Angka kesakitan= 37,35 per 100.000 penduduk dan Case Fatality Rate/angka kematian= 0,54 \%), sebanyak 30 dari 33 kabutaen/kota terjangkit DBD. ${ }^{3}$

Berdasarkan survei awal ke Dinas Kesehatan Kota Medan, didapati bahwa pada tahun 2017, kasus DBD di Kota Medan sebanyak 1216 kasus, dengan Kecamatan Medan Deli sebagai kecamatan dengan kasus terbanyak, yaitu sebanyak 100 kasus. Menurut WHO, DBD dapat dikendalikan dengan mengontrol vektor penyakit DBD yaitu nyamuk Ae. Aegypti, hal ini juga dikarenakan vaksin DBD belum dilaksanakan secara nasional dan tidak adanya obat yang spesifik untuk menatalaksana penyakit ini. ${ }^{2}$

Di Indonesia, Kementerian Kesehatan Repubik Indonesia dalam mencegah DBD terutama adalah dengan pemberantasan sarang nyamuk dengan gerakan 1 rumah 1 jumantik, dan juga diadakan upaya promosi kesehatan. ${ }^{4}$

Perilaku manusia sangat berpengaruh pada pengendalian Dengue ${ }^{5}$, karena berpengaruh pada kebersihan rumah, dan aktifitas, bila perilaku tidak baik maka nyamuk akan merasa nyaman untuk tinggal dan berkembang biak, karena nyamuk $A$. aegypti bersifat host seek. ${ }^{6}$

Berdasarkan kerucut pengalaman Edgar Dale, metode pembelajaran yang lebih banyak melibatkan berbagai indra, akan meningkatkan ingatan seseorang tentang sesuatu. Sebesar 70\% akan diingat seseorang dalam tulisan dan perkataannya tentang hal yang diajarkan bila mendapatkan pelajaran dengan metode role play, begitu juga bila seseorang berpartisipasi dalam permainan ${ }^{7}$

Chaharsoughi dalam penelitiannya yang berjudul "Comparison the Effect of Teaching of SBAR Technique with Role play and Lecturing on Communication Skill of Nurses", mendapatkan bahwa metode role play lebih efektif dalam mengajarkan Teknik SBAR. ${ }^{8}$ Yudianto dalam penelitiannya dengan judul Pengaruh Stimulasi Permainan Ular Tangga Terhadap Perubahan Sikap Siswa Tentang Demam Berdarah Dengue, bahwa penggunaan media stimulasi pemainan ular tangga yang telah dimodifikasi dengan penyuluhan penyakit DBD mempengaruhi peningkatan sikap siswa dalam pencegahan DBD. ${ }^{9}$ Penelitian peningkatan perilaku orang dewasa dengan metode permainan simulasi lain seperti ular tangga ${ }^{10,11}$, demontrasi ${ }^{12}$ dalam peningkatan perilaku kesehatan menunjukkan hasil yang signifikan dalam perubahan perilaku.

Penelitian peningkatan perilaku dengan metode role play belum dilakukan, dan apakah metode penyuluhan role play lebih efektif dibandingkan dengan metode permainan simulasi pada peningkatan pengetahuan, sikap dan tindakan ibu-ibu tentang DBD. Berdasarkan hal ini, maka peneliti tertarik untuk melakukan penelitian untuk membandingkan efektivitas penyuluhan kesehatan tentang DBD dengan memakai metode role play dengan metode permainan tentang DBD. Adapun tujuan penelitian ini adalah untuk mengetahui adanya perbedaan efektivitas antara metode penyuluhan role play dengan metode permainan pada 
peningkatan perilaku yaitu pengetahuan, sikap dan tindakan ibuibu tentang DBD.

\section{Metode Penelitian}

Desain penelitian ini adalah penelitian quasy experimental nonequivalent group design, di mana dilakukan pretest-posttest group design, dengan sampel tidak dipilih secara acak.

Penelitian ini dilaksanakan di kelompok ibu-ibu yang berdomisili di Kecamatan Medan Deli, Kota Medan, Sumatera Utara. Waktu penelitian pada Oktober 2018 sampai dengan Januari 2019. Kecamatan Medan Deli memiliki luas wilayah $2.197 \mathrm{Km}^{2}$, dengan jumlah penduduk sebesar 184.762 jiwa. Kelurahan Mabar terletak di tengah Kecamatan Medan Deli, dengan luas wilayah $456 \mathrm{Km}^{2}$ dengan jumlah penduduk sebesar 36.056 jiwa, kepadatan penduduk mencapai 7.907/ $\mathrm{Km}^{2}$. Kelurahan Mabar Hilir terletak di sebelah timur dari Kelurahan Mabar, dengan luas wilayah 316 $\mathrm{Km}^{2}$, dengan jmulah penduduk 29.165 jiwa, dengan kepadatan penduduk mencapai $9.229 / \mathrm{Km}^{2}$.

Populasi target adalah kepala rumah tangga dalam hal ini ibu, yang berdomisili di Kecamatan Medan Deli, Kota Medan, Sumatera Utara. Populasi terjangkau adalah ibu yang berdomisili di Kelurahan Mabar dan Kelurahan Mabar Hilir, Kecamatan Medan Deli, yang telah tergabung dalam suatu kelompok yang telah ada sebelum penelitian.

Sesuai dengan desain penelitian, maka pemilihan subjek penelitian adalah dengan purposive sampling, dengan jumlah subjek pada setiap kelompok, baik kelompok dengan perlakuan role play, mau pun kelompok permainan adalah 15 orang. Hal ini dengan pertimbangan kesesuaian dengan kriteria dari penyuluhan untuk kelompok kecil yaitu sebanyak kurang dari atau sama dengan 15 orang. Kelompok yang dipilih adalah kelompok yang telah ada di masyarakat.

Prosedur Penelitian

Peneliti meminta ijin pelaksanaan kegiatan pada pemerintah setempat di Kecamatan Medan Deli. Untuk metode role play peneliti membuat skenario yang terdiri dari 5 orang pemeran, yang berisi pengetahuan, sikap dan tindakan tentang DBD, dan mempersiapkan alat-alat yang membantu untuk pelaksanaan peragaan, seperti kaleng-kaleng kosong. Untuk metode permainan dipersiapkan alur permainan berbisik, permainan kata dan bahannya. Ditetapkan 2 kelompok yang menjadi kelompok perlakuan penyuluhan dengan role play dan kelompok penyuluhan dengan permainan

Kedua kelompok diberi kuesioner sebagai pre tes. Pernyataan pada pre tes dan post tes adalah sama, untuk menilai tingkat pengetahuan, sikap, dan tindakan tentang DBD.

Pada kelompok role play, hari pertama, peragaan diperagakan dahulu oleh kelompok penyuluh, kemudian pertemuan berikutnya, dibagi atas 3 grup yang terdiri dari 5 orang dan mengulang peragaan tersebut. Kelompok yang paling baik akan mendapat penghargaan. Pada kelompok permainan, pertemuan pertama diberi penyuluhan berupa ceramah dengan memakai power point, kemudian pada pertemuan kedua diadakan permainan berupa berbisik dan permainan kata, di mana kelompok ini juga dibagi dalam 3 grup yang terdiri dari 5 orang, dan yang menjadi pemenang akan mendapat penghargaan. Setelah dilakukan perlakuan maka diberi kuesioner sebagai post tes. Penghargaan pada kedua kelompok bernilai sama, dan dimaksudkan untuk menambah keinginan untuk berpartisipasi. Hasil pre tes dan post tes dianalisa.

Variabel dari penelitian ini adalah Metode Penyuluhan Role play dan Metode Penyuluhan Permainan sebagai variabel bebas, dan variabel terikat adalah Perilaku yang terdiri dari tingkat pengetahuan, sikap, dan tindakan Demam Berdarah Dengue.

Digunakan uji normalitas Shapiro-Wilk, dikarenakan jumlah subjek per kelompok kurang dari 50 subjek. Sesuai dengan hasil uji normalitas, didapati data terdistribusi normal, kemudian dipakai uji t berpasangan untuk melihat perbedaan rerata tiap kelompok perlakuan, Setelah itu post tes kedua metode dibandingkan dengan memakai uji t tidak berpasangan.

\section{Hasil}

Hasil uji t berpasangan menunjukkan peningkatan pengetahuan yang signifikan $(p<0,05)$ setelah diberikan penyuluhan pada masing-masing metode dengan nilai signifikansi sebesar $p$ 0,000. Rata-rata perubahan pengetahuan metode role play adalah 1.40 sedangkan metode permainan adalah 1.53 (Tabel 1).

Tabel 1. Nilai Rerata dan Kemaknaan Metode Role Play dan Permainan

\begin{tabular}{|c|c|c|c|c|c|}
\hline & $\mathbf{n}$ & $\begin{array}{c}\text { Rerata } \\
\pm \text { SD }\end{array}$ & $\begin{array}{c}\text { Perbedaan } \\
\text { Rerata } \\
\pm \text { SD } \\
\end{array}$ & $\mathrm{Cl} 95 \%$ & $p$ \\
\hline $\begin{array}{c}\text { Perilaku } \\
\text { peserta Role } \\
\text { play Pre tes }\end{array}$ & 15 & $\begin{array}{l}9,80 \pm \\
1,207\end{array}$ & \multirow{2}{*}{$\begin{array}{c}1,400 \pm \\
1,056\end{array}$} & \multirow{2}{*}{$\begin{array}{c}0,815- \\
1,985\end{array}$} & \multirow{2}{*}{0,000} \\
\hline $\begin{array}{c}\text { Perilaku } \\
\text { Peserta Role } \\
\text { play Post tes }\end{array}$ & 15 & $\begin{array}{c}11,20 \pm \\
1,082 \\
\end{array}$ & & & \\
\hline $\begin{array}{c}\text { Perilaku } \\
\text { Peserta } \\
\text { Permainan Pre } \\
\text { tes }\end{array}$ & 15 & $\begin{array}{r}11,33 \pm \\
1,113\end{array}$ & \multirow{2}{*}{$\begin{array}{c}1,533 \pm \\
1,356\end{array}$} & \multirow{2}{*}{$\begin{array}{c}0,789- \\
2,284\end{array}$} & \multirow{2}{*}{0,001} \\
\hline $\begin{array}{c}\text { Perilaku } \\
\text { Peserta } \\
\text { Permainan Post } \\
\text { tes } \\
\end{array}$ & 15 & $\begin{array}{c}12,87 \pm \\
1,060\end{array}$ & & & \\
\hline
\end{tabular}

Hasil uji t tidak berpasangan (Tabel 2), memperlihatkan terdapat perbedaan yang bermakna antara rata-rata nilai post tes antara metode role play dengan metode permainan.

Tabel 2. Uji T tidak berpasangan metode role play dengan metode permainan

\begin{tabular}{|c|c|c|c|c|}
\hline & $\mathrm{n}$ & $\begin{array}{c}\text { Rerata } \\
\pm \text { SD }\end{array}$ & $\begin{array}{l}\text { Perbedaan } \\
\text { Rerata } \pm \text { SD } \\
\text { Cl } 95 \%\end{array}$ & $p$ \\
\hline $\begin{array}{l}\text { Perilaku peserta } \\
\text { Role play }\end{array}$ & 15 & $\begin{array}{c}11,20 \\
\pm \\
1,082 \\
\end{array}$ & \multirow{2}{*}{$-1,67(0,86-2,47)$} & \multirow{2}{*}{0,000} \\
\hline $\begin{array}{l}\text { Perilaku Peserta } \\
\text { Role play Post tes }\end{array}$ & 15 & $\begin{array}{c}12,87 \\
\pm \\
1,060\end{array}$ & & \\
\hline
\end{tabular}

Dengan menggunakan perbandingan antara nilai t hitung (4.261) dengan $t$ tabel (2.048), maka t hitung $>t$ tabel, maka dapat ditarik kesimpulan yang sama, bahwa terdapat perbedaan yang bermakna antara rata-rata nilai post tes antara metode role play dengan metode permainan, dengan kata lain penerapan metode role play dengan metode permainan pada peningkatan perilaku 
DBD akan menghasilkan nilai yang berbeda. Hal ini juga memperlihatkan bahwa nilai rerata post tes pada penerapan metode role play lebih rendah dibanding dengan metode permainan. Dalam perhitungan juga didapatkan nilai t hitung yang negatif, yang artinya nilai rerata post tes metode role play didapati lebih rendah dari rerata nilai post tes metode permainan. Dengan kata lain metode role play tidak lebih efektif dibandingkan dengan metode permainan simulasi lainnya.

Tabel 3. Distribusi Frekuensi Karakteristik

\begin{tabular}{lllll}
\hline Karakteristik & Keterangan & $\mathbf{n}$ & \multicolumn{1}{c}{$\%$} \\
\hline Usia & $<35$ tahun & 14 & 46,7 \\
Pekerjaan & $\geq 35$ tahun & 16 & 53,3 \\
\multirow{4}{*}{ Pendapatan } & Tidak bekerja & 21 & 70 \\
& Bekerja & 9 & 30 \\
Pendidikan & <Rp 2,5 juta & 24 & 80 \\
terakhir & <Sp 2,5 juta & 6 & 20 \\
\hline
\end{tabular}

Dari Tabel 3 dapat dilihat bahwa persentase tertinggi adalah subkategorik usia $\geq 35$ tahun (53.3\%), tidak bekerja (70\%), pendapatan per bulan di bawah 2,5 juta rupiah (80\%), sedangkan untuk pendidikan terakhir baik di bawah SMA mau pun SMA ke atas memiliki persentase yang berimbang.

\section{Pembahasan}

Pada penelitian ini didapati bahwa rerata nilai post tes yang didapat melalui metode permainan lebih tinggi dibanding dengan metode role play. Menurut Supratiknya, metode role play membutuhkan waktu persiapan dan informasi tambahan tentang peran yang akan dimainkan, peserta harus memahami juga tentang tujuan, sudut pandang, dan fakta-fakta tambahan mengenai perannya sendiri, atau pun jalan cerita keseluruhan. ${ }^{13}$ $\mathrm{Hal}$ ini memyebabkan waktu yang diperlukan lebih lama dibandingkan dengan metode permainan. Metode permainan juga merupakan metode yang membangkitkan minat dan energi, dan dalam pelaksanaannya memancing keluar kecenderungankecenderungan ilmiah peserta dan memberikan umpan balik terhadap hal tersebut. Metode ini juga mendorong peserta untuk berpartisipasi secara penuh dalam pelaksanaanya. ${ }^{13}$

Walau pun begitu kedua metode permainan simulasi ini menunjukkan peningkatan perilaku ibu tentang DBD, sesuai dengan penelitian yang menunjukkan bahwa penerapan metode role play dan metode permainan lebih baik dari metode ceramah. ${ }^{14} .15$

Penelitian yang dilakukan oleh Lawalata, dkk menunjukkan metode role play meningkatkan pengetahuan kader tentang tuberculosa dan penularannya. ${ }^{12}$ Baik metode role play dan metode permainan termasuk dalam metode simulasi, yang menurut kerucut pengalaman Edgar Dale, peserta akan mengingat $70 \%$ apa yang mereka tulis dan katakan, dengan hasil diharapkan adalah peserta mampu menganalisa, mendesain, mengkreasi, dan mengevaluasi pengetahuan yang didapat. ${ }^{7}$

\section{Kesimpulan}

Dari penelitian ini didapati peningkatan rerata dari pre ke post pemberian metode role play dan metode permainan dan memberikan perbedaaan yang bermakna dalam peningkatan perilaku ibu-ibu tentang DBD. Penerapan metode role play kurang efektif dibandingkan dengan metode permainan.

\section{Ucapan Terima Kasih}

Peneliti mengucapkan terima kasih kepada Universitas HKBP Nommensen yang telah mendanai penelitian ini. Ucapan terima kasih juga saya sampaikan kepada Lurah dan seluruh staff Kelurahan Mabar dan Mabar Hilir, serta kelompok ibu-ibu yang bersedia membantu dan turut serta dalam penelitian ini.

\section{Daftar Pustaka}

1. WHO. WHO Fact Sheet [Internet]. World Health Organisation. 2015. p. 58. Available from: http://www.searo.who.int/entity/vector_borne_tropical_diseases/data/data_f actsheet/en

2. World Health Organization (WHO). Prevention and Control of Dengue and Dengue Haemorrhagic Fever [Internet]. World Health Organization; 2011. Available from: http://apps.searo.who.int/pds_docs/B4751.pdf?ua=1

3. Kementrian Kesehatan Republik Indonesia. Profil Kesehatan Indonesia 2017. Jakarta: Kementerian Kesehatan Republik Indonesia; 2018.

4. Kementerian Kesehatan Republik Indonesia. infodatin dbd 2016. Jakarta: Kementrian Kesehatan Republik Indonesia; 2016. p. 10.

5. Hayden \& Webb. Dengue. NSW Public Heal Bulleti. 2011 Sep;22(5-6):128.

6. Padmanabha H, Correa F, Rubio C, Baeza A, Osorio S, Mendez J, et al. Human social behavior and demography drive patterns of fine-scale dengue transmission in endemic areas of colombia. PLoS One. 2015;10(12):1-21.

7. Booth C. Reflective Teaching, Effective Learning: Instructional Literacy for Library Educators [Internet]. Chicago: American Library Association; 2011. 40 p. Available from: https://books.google.co.id/books?id=4xu20384p4AC\&printsec=frontcover\& $\mathrm{dq}=$ edgar+dale+cone+of+experience+2010\&hl=en\&sa=X\&ved=0ahUKEwi E96WNu9vWAhXFKo8KHbOhBoMQ6AEIVjAJ\#v=onepage\&q\&f=false

8. Chaharsoughi NT, Ahrari S, Alikhah S. Comparison the Effect of Teaching of SBAR Technique with Role play and Lecturing on Communication Skill of Nurses. 2014;3(2):141-7.

9. Yudianto A. Pengaruh Stimulasi Permainan Ular Tangga Terhadap Perubahan Sikap Siswa Tentang Demam Berdarah Dengue. 2011;2011:6.

10. Pengaruh Penyuluhan Metode Stimulasi Game Pada Kader Dalam Memberi Stimulasi Kognitif Anak Stunting Di Wilayah Puskesmas Kenjeran | Arini | Jurnal Pengabdian Kesehatan [Internet]. [Cited 2021 Jul 30]. Available From:

https://Jpk.Jurnal.Stikescendekiautamakudus.Ac.Id/Index.Php/Jpk/Article/V iew/66/38

11. Ayu So. Efektifitas Pemberian Penyuluhan Kesehatan Dengan Metode Demonstrasi Terhadap Keterampilan Ibu Dalam Penanganan Tersedak Pada Anak Usia 2-5 Tahun Di Tk Negeri Pembina Ngawi. 2020 Jan 21;

12. Ifroh RH, Permana L. Kombinasi Metode Permainan dan Demonstrasi dalam Meningkatkan Pengetahuan Ibu tentang Stunting. J IIm Kesehat Masy Media Komun Komunitas Kesehat Masy [Internet]. 2021 Mar 6 [cited 2021 Jul 30];13(1):1-6. Available from: https://jikm.upnvj.ac.id/index.php/home/article/view/124

13. Supratiknya A. Merancang Program dan Modul Psikoedukasi. Revisi. Yogyakarta: Universitas SanataDharma; 2011. 90-100 p.

14. Martiani. EFEKTIVITAS PELATIHAN KETRAMPILAN KOMUNIKASI UNTUK MENINGKATKAN KUALITAS HUBUNGAN IBU-REMAJA. Surakarta: Universitas Muhammadyah Surakarta; 2016.

15. Pratiwi D, Yuniar N, Erawan PE. Pengaruh Penyuluhan Metode Permainan Edukatif dan Metode Ceramah Terhadap Pengetahuan, Sikap dan Tindakan Tentang Pencegahan Penyakit Diare Pada Murid Sd Di Kecamatan Poasia Kota Kendari Tahun 2015. J IIm Mhs Kesehat Masy [Internet]. 2015;1. Available from: ojs.uho.ac.id/index.php/JIMKESMAS/article/view/664 